\title{
PERBANDINGAN ANTARA PEMBERIAN KEJU OLES OLAHAN DENGAN DAN TANPA PASTA CPP-ACP TERHADAP KEKERASAN PERMUKAAN ENAMEL
}

\author{
(COMPARISON BETWEEN TOPICAL APPLICATON PROCESSED CHEESE \\ AND CPP-ACP PASTE TO ENAMEL SURFACE HARDNESS)
}

\author{
Darwis Aswal, Fitri Yunita Batubara, Eka Sansari Panggabean \\ Departemen Konservasi \\ Fakultas Kedokteran Gigi, Unversitas Sumatera Utara \\ Jl. Alumni no. 2 Kampus USU Medan \\ E-mail: darwisaswal@yahoo.co.id
}

\begin{abstract}
The ability tooth remineralization agents to remineralize the tooth can be detected by an increase of enamel surface hardness. The purpose of this study was to determine the comparison between applicaton processed cheese topically with casein phosphopeptide- amorphous calcium phosphate (CPP-ACP) paste to enamel surface hardness. This study used a sample of 30 extracted human third molar. All sample was immersed in carbonated drink for 10 minutes three times a day for 3 days to cause demineralization. Then, sample was applied with agent according to their group: group I wasn't applied any agent as control, group II was applied with processed cheese and group III was applied with CPP-ACP paste. This procedure was done for 5 minutes three times a day for 5 days. Hardness test with Microvickers Hardness Tester was done three times: before treatment, after immersed in carbonated drink and after application of remineralizing agents. Data that obtained was analized with Oneway ANOVA and Bonferoni. The result of this study showed the significant elevation of enamel surface hardness in group processed cheese spread and CPP-ACP paste with mean value 41, 42 and 71, $43 \mathrm{VHN}$ (Vickers Hardenss Number). There is a significant difference between application processed cheese spread and CPP-ACP paste to enamel surface hardness. In conclusion, CPP-ACP paste can elevate enamel surface hardness better than processed cheese spread.
\end{abstract}

Key words: erosion, CPP-ACP, cheese spread

\begin{abstract}
Abstrak
Kemampuan bahan remineralisasi dalam meremineralisasi gigi dapat diketahui dengan meningkatnya kekerasan permukaan gigi. Tujuan penelitian ini adalah untuk mengetahui perbandingan antara pemberian keju oles olahan dengan pasta casein phosphopeptide- amorphous calcium phosphate (CPP-ACP) terhadap kekerasan permukaan enamel. Penelitian ini menggunakan sampel 30 buah gigi molar tiga manusia yang sudah diekstraksi. Seluruh sampel direndam dalam minuman berkarbonasi selama 10 menit sebanyak tiga kali sehari selama 3 hari untuk menimbulkan demineralisasi. Setelah itu, sampel diberi bahan uji sesuai kelompoknya yaitu kelompok I tidak diberi bahan uji sebagai kontrol, kelompok II diberi keju oles olahan dan kelompok III diberi pasta CPP-ACP. Prosedur dilakukan selama 5 menit sebanyak tiga kali sehari selama 5 hari. Pengujian menggunakan Microvickers Hardness Tester dilakukan sebanyak tiga kali: sebelum perlakuan, setelah perendaman dalam minuman berkarbonasi dan setelah pemberian bahan uji. Data yang diperoleh selanjutnya dianalisis dengan uji Oneway ANOVA dan Bonferroni. Hasil penelitian menunjukkan terjadinya peningkatan nilai kekerasan permukaan enamel yang signifikan $(\mathrm{p}<0,05)$ pada kelompok keju oles oahan dan pasta CPP-ACP dengan ratarata sebesar 41,42 VHN dan 71,43 VHN. Ada perbedaan yang signifikan antara pemberian keju oles olahan dengan pasta CPP-ACP terhadap kekerasan permukaan enamel. Sebagai kesimpulan, pasta CPP-ACP dapat meningkatkan kekerasan permukaan enamel lebih baik dari keju oles olahan.
\end{abstract}

Kata kunci: erosi, CPP-ACP, keju oles 


\section{PENDAHULUAN}

Seiring berubahnya pola hidup dalam beberapa dekade, jumlah dan frekuensi konsumsi makanan dan minuman asam telah meningkat. Ketersediaan dan frekuensi konsumsi makanan dan minuman asam yang bervariasi pada zaman sekarang telah menjadi faktor signifikan dalam meningkatkan terjadinya erosi gigi. Faktor biologis seperti saliva, pelikel gigi dan struktur gigi berhubungan dengan perkembangan erosi. Saliva telah menunjukkan sebagai faktor biologis yang paling penting dalam pencegahan erosi gigi. Namun, saliva memiliki keterbatasan terutama dalam menghadapi serangan erosi yang cukup berat oleh karena itu tindakan pencegahan harus dilakukan untuk mengurangi proses erosi dan meningkatkan faktor-faktor perlindungan yang akan membawa kembali keseimbangan dalam lingkungan rongga mulut. Secara teoritis, peningkatan kalsium, fosfat dan ion fluor pada cairan rongga mulut adalah kondisi yang baik untuk memicu terjadinya remineralisasi pada enamel dan menghambat demineralisasi. ${ }^{1,2}$

Bahan remineralisasi berguna untuk mengontrol siklus demineralisasi dan remineralisasi melalui lingkungan mikro di sekitar gigi. Salah satu bahan remineralisasi yang dikenal dan banyak digunakan di kedokteran gigi adalah CPP-ACP yaitu senyawa yang dihasilkan dari intisari trypticcasein yang bergabung dengan fosfat dan dimurnikan melalui ultrafiltrasi. CPP yang berukuran nanocomplex memungkinkannya untuk masuk melalui gradien konsentrasi ke dalam badan atau bawah permukaan lesi dan menimbulkan remineralisasi. $^{3}$

Selain pasta CPP-ACP, sejumlah besar CPP ditemukan dalam keju karena adanya aktivitas proteolitik. Keju adalah makanan hasil fermentasi susu yang juga menjadi sumber konsentrat beberapa nutrisi susu. Beberapa hipotesis mengenai keju telah dimunculkan terkait kemampuannya mencegah demineralisasi, memicu remineralisasi, serta kemampuan menetralisir asam karena hasil metabolisme protein, kandungan kasein, kalsium laktat, ion kalsium dan ion fosfat. ${ }^{4-6}$

Terdapat banyak jenis keju di seluruh dunia dengan spesifikasinya masing-masing di FDA (Food Drug and Administration) salah satunya yaitu keju oles olahan. Keju oles olahan yaitu perpaduan beberapa keju segar yang dicampur dan dipanaskan dengan tambahan garam sebagai pengemulsi tanpa proses pematangan. Hal ini menyebabkan keju memiliki tekstur lunak dan dapat dioles pada suhu ruangan. Sebagaimana keju pada umumnya, keju oles olahan juga mengandung sejumlah besar mineral seperti kalsium dan fosfat yang berperan penting dalam meremineralisasi gigi. Namun harganya yang murah serta ketersediaannya yang mudah ditemukan menjadikan keju oles olahan memiliki kelebihan sebagai bahan remineralisasi gigi yang alami. ${ }^{7-8}$

Kekerasan enamel secara mikro dapat diukur menggunakan sebuah alat yang dikenal dengan Microvickers Hardness Tester. Microvickers Hardness Tester telah secara luas digunakan untuk mengetahui perubahan pada permukaan enamel. Dengan tes ini, tahap awal pelarutan enamel yang berkaitan dengan demineralisasi dan pelemahan permukannya dapat diketahui. Sebaliknya, tes ini juga dapat mengetahui penambahan mineral pada permukaan gigi yang mengindikasikan terjadinya remineralisasi strukturnya. ${ }^{1}$

Tujuan dari penelitian ini adalah untuk mengetahui ada tidaknya perbedaan antara pemberian keju oles olahan dengan pasta CPP-ACP terhadap kekerasan permukaan enamel.

\section{BAHAN DAN METODE}

Penelitian ini telah mendapatkan persetujuan komisi etik penelitian kesehatan dengan nomor surat 290/ KOMET/FK USU/2016. Sampel gigi dibersihkan menggunakan bubuk pumice dan bur brush kemudian dibilas dengan aquades hingga bersih. Sampel dipotong pada bagian DEJ (dentoenameljunction) menggunakan diamond disc dan micromotor low speed. Mahkota gigi yang sudah dipotong ditanam dalam resin akrilik self cured ukuran $2 \times 2 \times 1 \mathrm{~cm}$ dengan permukaan bukal menghadap ke atas.

Sampel secara acak dikelompokkan menjadi tiga kelompok. Bagian bawah balok akrilik diberi tanda untuk memudahkan pengelompokan. Kekerasan permukaan awal masing-masing gigi diukur menggunakan alat uji Microvickers Hardness Tester. Sampel diletakkan di atas meja obyek pada alat Microvickers Hardness Tester tepat di tengah lensa dan difokuskan dengan memutar pegangan untuk fokus searah jarum jam.

Setelah gambar tampak fokus, tombol start ditekan, lensa bergeser berganti dengan diamond indentor. Ujung diamond indentor turun menekan sampel dengan beban $300 \mathrm{gf} / 15$ detik. Diamond indentor akan naik dan bergeser berganti dengan lensa seperti pada posisi semula. Hasil penetrasi diamati melalui lensa mikroskop dengan pembesaran 400 kali sehingga akan tampak bentukan piramida (Gambar 1) .

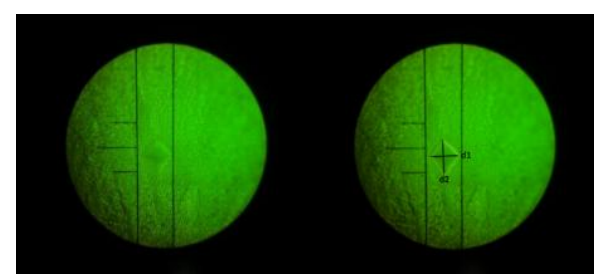


Gambar 1. Bentukan piramida yang terlihat pada mikroskop alat Micro-vickers Hardness Tester

Panjang diagonal yang dihasilkan indentor diukur dengan menempatkan 2 tanda garis pada ujung bentukan piramida yang ada pada alat Microvickers Hardness Tester, kemudian tombol baca ditekan sehingga keluar hasil kekerasan permukaan dengan satuan Vickers Hardness Number (VHN) (Gambar 2).

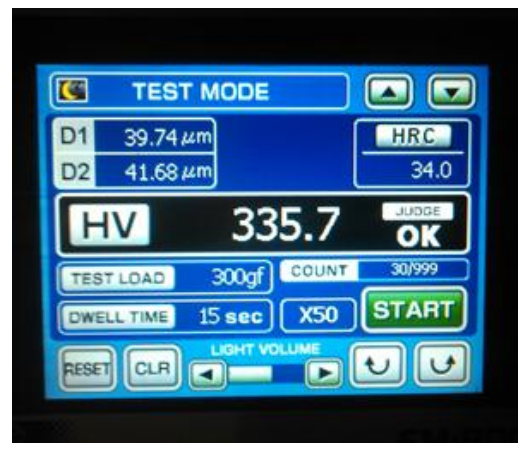

Gambar 2. Nilai kekerasan yang muncul pada layar alat

Proses demineralisasi dilakukan dengan merendam sampel ke dalam minuman berkarbonasi jenis cola. Sebelumnya $\mathrm{pH}$ cola diukur menggunakan $\mathrm{pH}$ meter. Perendaman dilakukan pada suhu ruangan selama 10 menit. Lalu sampel dibilas dengan aquadest. Proses dilakukan sebanyak 3 kali sehari dengan interval waktu 6 jam. Prosedur diulangi selama 3 hari berturut-turut. Selama interval, sampel direndam dalam saliva buatan dan disimpan dalam inkubator pada suhu $37^{\circ} \mathrm{C}$. Pengukuran kekerasan permukaan enamel kembali dilakukan. Selanjutnya adalah tahap pemberian bahan uji. Masing-masing sampel diberi bahan sesuai kelompoknya. Kelompok I tidak diberi bahan uji sebagai kontrol, kelompok II diberi keju oles olahan dan kelompok III diberi pasta CPP-ACP dengan cara dioles menggunakan micro brush secara merata pada permukaan bukal sampel dan dibiarkan selama 5 menit. Lalu sampel dibilas dengan aquadest. Proses dilakukan sebanyak 3 kali sehari dengan interval waktu 6 jam. Prosedur diulangi selama 5 hari berturut-turut. Selama interval, sampel direndam dalam saliva buatan dan disimpan dalam inkubator pada suhu $37^{\circ} \mathrm{C}$. Setelah semua prosedur selesai, pengukuran kekerasan permukaan enamel kembali dilakukan.

\section{HASIL}

Tabel 1 menunjukkan penurunan nilai rata-rata kekerasan permukaan enamel yang terjadi setelah perendaman dalam minuman berkarbonasi pada ketiga kelompok. Sebaliknya, nilai rata-rata kekerasan per- mukaan enamel meningkat setelah pemberian bahan uji yaitu kelompok I sebagai kontrol yang hanya direndam dalam saliva buatan, kelompok II yang diberi keju oles olahan dan kelompok III yang diberi pasta CPP-ACP.

Tabel 1. Nilai rata-rata kekerasan permukaan enamel sebelum perlakuan, setelah perendaman dalam minuman berkarbonasi dan setelah pemberian bahan uji

\begin{tabular}{lccc}
\hline \multirow{2}{*}{ Waktu } & \multicolumn{3}{c}{ Kelompok } \\
& X \pm SD (VHN) \\
\cline { 2 - 4 } & I & II & III \\
\hline Sebelum perlakuan & $347,77 \pm 35,42$ & $349,02 \pm 35,17$ & $363,20 \pm 21,95$ \\
$\begin{array}{l}\text { Setelah perendaman } \\
\text { dalam minuman }\end{array}$ & $233,78 \pm 40,72$ & $253,79 \pm 39,95$ & $259,62 \pm 27,42$ \\
berkarbonasi & & & \\
$\begin{array}{l}\text { Setelah pemberian } \\
\text { bahan uji }\end{array}$ & $254,05 \pm 36,62$ & $295,21 \pm 36,11$ & $332,05 \pm 24,82$ \\
\hline
\end{tabular}

Tabel 2 menunjukkan perbedaan rata-rata peningkatan kekerasan permukaan enamel antar kelompok setelah pemberian bahan uji yang mana peningkatan paling besar terjadi pada kelompok III (kelompok pasta CPP-ACP) yaitu sebesar 72,43 VHN. Pada kelompok II (kelompok keju oles olahan) terjadi peningkatan sebesar 41,42 VHN, dan kelompok I adalah yang mengalami peningkatan paling kecil yaitu sebesar 20,25 VHN. Peningkatan kekerasan pada ketiga kelompok tergolong signifikan $(\mathrm{p}<0,05)$. Selanjutnya untuk mengetahui signifikansi antar satu kelompok terhadap kelompok lainnya dilakukan uji Post Hoc Bonferroni.

Tabel 2. Hasil uji statistik Oneway ANOVA perbandingan peningkatan kekerasan permukaan enamel antar kelompok setelah pemberian bahan uji

\begin{tabular}{lcc}
\hline \multicolumn{1}{c}{ Kelompok } & $\mathrm{X} \pm \mathrm{SD}(\mathrm{VHN})$ & $\mathrm{P}$ \\
\hline Kontrol & $20,270 \pm 16,69$ & 0,001 \\
Keju oles olahan & $41,420 \pm 28,39$ & 0,001 \\
Pasta CPP-ACP & $72,430 \pm 31,73$ & 0,001 \\
\hline
\end{tabular}

* Terdapat perbedaan signifikan pada level $\mathrm{p}<0,05$

Tabel 3 menunjukkan hasil uji Post Hoc Bonferroni terhadap perbandingan peningkatan kekerasan permukaan enamel antar kelompok. Hasil statistik menunjukkan kelompok kontrol tidak memiliki perbedaan signifikan dengan kelompok keju oles olahan ( $>0,05)$. Sebaliknya terdapat perbedaan yang signifikan antara kelompok kontrol terhadap kelompok pasta CPP-ACP maupun kelompok keju oles olahan terhadap kelompok pasta CPP-ACP $(\mathrm{p}<0,05)$.

Tabel 3. Hasil uji Post Hoc Bonferroni perbandingan peningkatan keke-rasan permukaan enamel antar kelompok setelah pemberian bahan uji

\begin{tabular}{cccc}
\hline I (Kelompok) & J (Kelompok) & Mean $($ VHN $)$ & p \\
\hline Kontrol & Keju oles olahan & $-21,17$ & 0,253 \\
& Pasta CPP-ACP & $-52,18^{*}$ & 0,000
\end{tabular}





\begin{tabular}{llcc} 
Keju oles olahan & Kontrol & 21,17 & 0,253 \\
& Pasta CPP-ACP & $-31,01^{*}$ & 0,042 \\
Pasta CPP-ACP & Kontrol & $52,18^{*}$ & 0,000 \\
& Keju oles olahan & $31,01^{*}$ & 0,042 \\
\hline
\end{tabular}

* Terdapat perbedaan signifikan pada level $\mathrm{p}<0,05$

\section{PEMBAHASAN}

Pengujian microhardness dipertimbangkan sebagai metode yang sederhana dan dapat dipercaya untuk menentukan informasi secara tidak langsung terhadap perubahan kandungan mineral pada enamel. Penambahan atau hilangnya mineral sebagai proses remineralisasi dan demineralisasi dapat diukur dengan perubahan kekerasannya. Untuk mengukur kekerasan permukaan enamel, penelitian ini mengikuti metode yang dilakukan oleh Bansode et al. yaitu dengan menggunakan permukaan enamel utuh tanpa polishing sehingga lebih akurat dalam mencerminkan siklus erosi dan demineralisasi pada lingkungan rongga mulut. ${ }^{9-10}$

Pada penelitian ini, hasil menunjukkan terjadinya penurunan kekerasan permukaan enamel pada ketiga kelompok perlakuan setelah direndam dalam minuman berkarbonasi dengan rata-rata sebesar 96-114 VHN. Minuman ringan memiliki banyak pengaruh masalah kesehatan termasuk kesehatan gigi seperti karies dan erosi. Tingginya kandungan asam dalam minuman ringan seperti minuman berkarbonasi adalah penyebab utama erosi gigi. Faktor lain yang mempengaruhi kemampuan erosif dari minuman berkarbonasi adalah proses yang berhubungan dengan penekanan karbon dioksida $\left(\mathrm{CO}_{2}\right)$ menjadi air $\left(\mathrm{H}_{2} \mathrm{O}\right)$ dan memproduksi asam karbonat $\left(\mathrm{H}_{2} \mathrm{CO}_{3}\right)$ yang berdampak pada semakin menurunnya $\mathrm{pH}$ dari minuman tersebut. Penurunan nilai rata-rata kekerasan permukaan enamel pada ketiga kelompok setelah perendaman dalam minuman berkarbonasi disebabkan oleh rendahnya $\mathrm{pH}$ minuman berkarbonasi yaitu 2,65. Kemampuan erosif dari minuman berkarbonasi seperti cola juga disebabkan karena kandungan asam fosfatnya. Hal ini sesuai dengan pernyataan Lodi et al. pada tahun 2010 yang mempelajari efek berbagai minuman berkarbonasi terhadap gigi hewan. Hasilnya menunjukkan bahwa asam fosfat lebih erosif daripada asam sitrat, malic, dan tartaric serta asam fosfat lebih mampu untuk melarutkan kalsium. ${ }^{10}$

Setelah perendaman dalam minuman berkarbonasi, ketiga kelompok selanjutnya diberi bahan uji sesuai kelompoknya masing-masing. Hasil uji statistik Oneway ANOVA menunjukkan terjadinya peningkatan kekerasan permukaan enamel pada ketiga kelompok dengan rata-rata sebesar 20,27 VHN pada kelompok I yaitu kelompok yang hanya direndam dalam saliva buatan, 41,42 pada kelompok II yaitu yang diberi keju oles olahan dan 71,43 pada kelompok III yaitu yang diberi past CPP-ACP.

Dalam penelitian mengenai erosi, saliva merupakan faktor yang penting dipertimbangkan yang mana saliva bertindak sebagai pelindung yang mencoba menghentikan penyebaran asam ke permukaan gigi. Peningkatan kekerasan permukaan enamel pada kelompok kontrol yang disimpan dalam saliva buatan ini sesuai dengan hasil penelitian sebelumnya yang dilakukan oleh Marilia et al. pada tahun 2011 yang menunjukkan saliva buatan meningkatkan rata-rata kekerasan permukaan enamel setelah demineralisasi oleh cola. Saliva memiliki aksi buffering yang dapat menetralkan $\mathrm{pH}$ di sekitar lingkungan gigi serta mengandung sejumlah mineral yang berperan dalam proses remineralisasi. Devlin et al. pada tahun 2006 pada penelitiannya juga menemukan bahwa minuman berkarbonasi dapat menurunkan rata-rata kekerasan permukaan enamel gigi dan saliva buatan dapat mengembalikan sebagian kekerasannya. ${ }^{1,10}$

Pada kelompok keju oles olahan peningkatan yang lebih besar terlihat dibanding dengan kelompok kontrol. Hal ini dikarenakan keju memiliki kandungan kalsium dan fosfor yang tinggi, mineral penting yang diperlukan dalam perbaikan struktur hidroksiapatit. Keju juga diketahui mengandung persentase yang tinggi terhadap casein phosphopeptides (CPP). CPP dalam bentuk senyawa yang dapat larut dengan kalsium efektif mencegah pengendapan kalsium fosfat dan meningkatkan absorbsi mineral ini ke permukaan gigi. Produk susu seperti keju sangat kaya dengan multiphosphorylated peptida seperti CPP yang dapat berinteraksi dengan kalsium fosfat dan menimbulkan remineralisasi pada gigi. Mekanismenya adalah melalui efek kimia secara langsung dari kandungan kasein dan kalsium fosfatnya. Enamel gigi adalah substansi polymeric yang mengandung kristalin kalsium fosfat, tertanam dalam matriks protein. Hal itu menyebabkan CPP dapat secara signifikan meningkatkan lokalisasi amorphous calcium phosphate (ACP) pada permukaan gigi, mencegah demineralisasi enamel dan memicu remineralisasinya. Penelitian yang dilakukan oleh Galina et al. pada tahun 2015 tentang efek pemberian bahan makanan terhadap enamel yang terpapar minuman asam dengan sampel gigi manusia yang diekstraksi untuk keperluan ortodonti juga menunjukkan hasil serupa bahwa keju Parmezan dapat mengurangi penurunan kekerasan permukaan gigi akibat minuman cola. ${ }^{6,811}$

Apabila dibandingkan kedua kedua kelompok lainnya, peningkatan paling besar terjadi pada kelompok III yaitu yang diberi pasta CPP-ACP. Pasta CPP-ACP yang digunakan dalam penelitian ini adalah yang sudah tersedia dalam bentuk produk dengan merek dagang Recaldent-Tooth Mousse ${ }^{\mathrm{TM}}$. Sebagaimana dike- 
tahui tooth mousse adalah salah satu bahan remineralisasi yang sering digunakan dalam kedokteran gigi. Pasta ini telah diklaim dapat melawan demineralisasi, meningkatkan aliran saliva, meningkatkan penyerapan fluor dan meredakan permukaan gigi yang sensitif, mengembalikan mineral dan menguatkan enamel gigi, mengurangi asam yang tinggi pada rongga mulut setelah konsumsi minuman ringan yang berlebihan, dan menetralkan asam plak dan bakteri. Pasta ini diklaim dapat menstabilkan ion kalsium dan fosfat dalam konsentrasi tinggi dengan mengikat ACP dengan pelikel dan plak pada permukaan gigi. Penelitian yang pernah dilakukan oleh Turssi et al. pada tahun 2011 tentang efek berbagai bahan remineralisasi terhadap enamel yang terpapar asam menggunakan sampel gigi in-sisivus sapi dan menemukan hasil bahwa pasta CPP-ACP dapat meningkatkan remineralisasi enamel yang terpapar asam yang disimulasikan asam ekstrinsik seperti minuman ringan., ${ }^{4}, 12,13$

Hal ini mungkin disebabkan CPP yang terkandung dalam tooth mousse sudah sepenuhnya mengikat kalsium dan fosfat dalam bentuk ACP yang mana senyawa ini dapat langsung masuk ke dalam permukaan enamel dan menimbulkan remineralisasi. Sementara itu CPP pada keju masih harus menstabilkan kalsium fosfat dalam larutan agar dapat membentuk CPP-ACP dalam bentuk nanocomplex. ${ }^{4}$

Faktor lain yang mungkin menyebabkan kemampuan remineralisasi tooth mousse lebih baik dari keju oles

\section{DAFTAR PUSTAKA}

1. Porcelli HBP, Maeda FA, Silva BR, Miranda WG, Cordoso PEC. Remineralizing agents: effects on acidsoftened enamel. General Dentistry 2015: 73.

2. Lussi. Dental erosion from diagnosis to therapy. Switzerland: CH-3010 Bern 2006; 20: 11-27.

3. Tyagi SP, Garg P, Sinha DJ, Singh UP. An update on remineralizing agents. J Int Dent 2015; 3(3): 152.

4. Pinto et al. Bioactive casein phosphopeptides in dairy products as nutraceuticals for functional foods. <http: //dx.doi.org/10.5772/50725> (22 Maret 2016).

5. Dairy Research Institute. Cheese: benefits and current issues. National Dairy Council 2011.

6. Galina P, Sandu AV, Andrian S, Stoleriu S. Effect of some food intake on erosive beverage action on dental enamel and cement. Material Plastic 2014; 51(4): 430.

7. Bastin S. Cheese basics. Agriculuture and Natural Resources J 2006; 1-4.

8. National Dairy Council. Cheese and healthy eating. Innovation Center for U.S. Dairy and National Dairy Council 2011. olahan adalah perbedaan jumlah CPP yang terkandung pada masing-masing bahan. Terdapat kemungkinan jumlah CPP yang terkandung dalam keju oles olahan tidak sebanyak seperti yang terkandung dalam tooth mousse. Hal ini dapat dikarenakan kandungan CPP yang terkandung dalam keju oles olahan dapat berkurang selama proses pengolahan keju. Selain itu, berbeda dengan tooth mousse yang memiliki $\mathrm{pH}$ di atas 7, hampir semua jenis keju diketahui memiliki $\mathrm{pH}$ yang cenderung asam yaitu berkisar antara 5,1 hingga 5,9. Dalam penelitian secara in vivo yang mana faktor saliva dihasilkan secara langsung oleh subjek manusia, pH keju yang cenderung asam diketahui tidak mempengaruhi kemampuan remineralisasinya karena keju membantu meningkatkan $\mathrm{pH}$ rongga mulut melalui stimulasi atau peningkatan laju alir saliva di dalam rongga mulut. Namun dalam penelitian secara in vitro, pH keju yang cenderung asam kemungkinan dapat menjadi penyebab berkurangnya kemampuan remineralisasi dari keju karena kondisi yang asam tersebut tidak diimbangi dengan peningkatan laju alir saliva di sekitar lingkungan gigi. ${ }^{4,14-15}$

Kesimpulan dari penelitian ini adalah terdapat perbedaan yang signifikan antara pemberian keju oles olahan dengan pasta CPP-ACP terhadap kekerasan permukaan enamel yang mana pasta CPP-ACP dapat meningkatkan kekerasan permukaan enamel lebih tinggi daripada keju oles olahan.

9. Bansode PV, Deore R, Pathak S. Evaluation of the effect of casein phosphopeptide- amorphous calcium phosphate on tooth enamel demineralized by a carbonated soft drink using micro hardness testing method: an in vitro study. Int J Sci Study 2014; 2(8): 24-8.

10. Hashim Qibi L, Aboody AA. Effect of fluoridated dentifrices on surface microhardness of the enameleroded by Coca-cola. Int J Enhanced Res in Sci Tech \& Eng 2014; 3(5): 181-7.

11. Shakra KA. Cariostatic effect of various cheeses on the degree of mineralisation of enamel in situ. JRMS 2013; 20(1): 53-60.

12. Hemagaran G, Neelakantan P. Remineralization of the tooth structure - the future of dentistry. Int J Pharm Tech Res 2014; 6(2): 487-93.

13. Turssi et al. Effect of potential remineralizing agents on acid softened enamel. American J Dentistry 2011; 24 (3): 165-8.

14. Hayden. The Effect of Cheese on the pH Levels in the Oral Cavity. Thesis. Kentucky: Western Kentucky University, 2015: 3-11.

15. Walsh L. Tooth mousse. http://gcasia.info (21 April 2016). 